Atmos. Chem. Phys., 17, 10743-10752, 2017

https://doi.org/10.5194/acp-17-10743-2017

(c) Author(s) 2017. This work is distributed under

the Creative Commons Attribution 3.0 License.

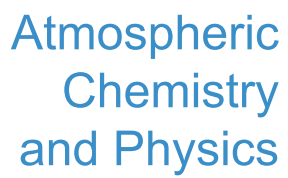

(c) (P)

\title{
Gasoline aromatics: a critical determinant of urban secondary organic aerosol formation
}

\author{
Jianfei Peng ${ }^{1, \mathrm{a}}$, Min Hu${ }^{1,4}$, Zhuofei Du${ }^{1}$, Yinhui Wang ${ }^{2}$, Jing Zheng ${ }^{1}$, Wenbin Zhang ${ }^{2}$, Yudong Yang ${ }^{1}$, Yanhong Qin ${ }^{1}$, \\ Rong Zheng $^{2}$, Yao Xiao ${ }^{1}$, Yusheng $\mathrm{Wu}^{1}$, Sihua $\mathrm{Lu}^{1}$, Zhijun Wu${ }^{1}$, Song Guo ${ }^{1}$, Hongjun $\mathrm{Mao}^{3}$, and Shijin Shuai ${ }^{2}$ \\ ${ }^{1}$ State Key Joint Laboratory of Environmental Simulation and Pollution Control, College of Environmental Sciences and \\ Engineering, Peking University, Beijing 100871, China \\ ${ }^{2}$ State Key Laboratory of Automotive Safety and Energy, Tsinghua University, Beijing 100084, China \\ ${ }^{3}$ College of Environmental Sciences and Engineering, Nankai University, Tianjin 300071, China \\ ${ }^{4}$ Beijing Innovation Center for Engineering Science and Advanced Technology, Peking University, Beijing 100871, China \\ ${ }^{a}$ now at: Department of Atmospheric Sciences, Texas A\&M University, College Station, TX 77843, USA
}

Correspondence to: Min Hu (minhu@pku.edu.cn) and Shijin Shuai (sjshuai@ tsinghua.edu.cn)

Received: 19 March 2017 - Discussion started: 27 March 2017

Revised: 27 July 2017 - Accepted: 15 August 2017 - Published: 13 September 2017

\begin{abstract}
Gasoline vehicle exhaust is an important contributor to secondary organic aerosol (SOA) formation in urban atmosphere. Fuel composition has a potentially considerable impact on gasoline SOA production, but the link between fuel components and SOA production is still poorly understood. Here, we present chamber experiments to investigate the impacts of gasoline aromatic content on SOA production through chamber oxidation approach. A significant amplification factor of 3-6 for SOA productions from gasoline exhausts is observed as gasoline aromatic content rose from 29 to $37 \%$. Considerably higher emission of aromatic volatile organic compounds (VOCs) using high-aromatic fuel plays an essential role in the enhancement of SOA production, while semi-volatile organic compounds (e.g., gas-phase PAHs) may also contribute to the higher SOA production. Our findings indicate that gasoline aromatics significantly influence ambient $\mathrm{PM}_{2.5}$ concentration in urban areas and emphasize that more stringent regulation of gasoline aromatic content will lead to considerable benefits for urban air quality.
\end{abstract}

\section{Introduction}

Fossil-fuel-powered vehicles, an important source of $\mathrm{NO}_{x}$, volatile organic compounds (VOCs) and atmospheric particulate matter (PM), are always associated with severe haze events, human health risks and climate forcing, particularly in urban areas (Parrish and Zhu, 2009; Guo et al., 2014; Huang et al., 2014; Kumar et al., 2014; S. Liu et al., 2015; Kelly and Zhu, 2016; Peng et al., 2016b). Gasoline is the most widely used vehicle fuel and accounts for the largest total transportation energy consumptions in many countries, e.g., the USA and China (NBSC, 2015; EIA, 2017). Among all the gasoline-related PM components, secondary organic aerosol (SOA) produced via atmospheric oxidation of VOC precursors in the exhaust has been proved by chamber experiments to be a large fraction, if not the largest, of gasoline vehicular PM (Zervas et al., 1999; Jimenez et al., 2009; Gordon et al., 2014a; Jathar et al., 2014; Platt et al., 2014; T. Liu et al., 2015). Moreover, ambient measurement also demonstrated that gasoline SOA was the largest source of vehicular carbonaceous PM in megacities such as Los Angeles (Bahreini et al., 2012). However, although increasingly stringent gasoline fuel standards, especially on sulfur content, have been implemented in the past decades in many countries to reduce the emissions, the impacts of fuel compositions on SOA production have not been sufficiently taken into account in the current gasoline fuel standards. This deficiency is mainly attributed to the poor understanding of the effects of fuel properties on the related SOA formation, and may ultimately lead to a policy bias on the control of vehicle emission regarding the reduction of atmospheric pollution. 
Aromatic hydrocarbons, which are unsaturated compounds with at least one benzene ring, account for 20$40 \% v / v$ of gasoline fuel. Aromatic VOCs (e.g., toluene, xylenes and trimethylbenzenes) react exclusively with the $\mathrm{OH}$ radical in the atmosphere, leading to the formation of a variety of semi- or low-volatility species (e.g., benzoic acid) (Zhang et al., 2015; Schwantes et al., 2017), which will partition onto existing particles and be recognized as anthropogenic SOA. Therefore, the higher emission of aromatic VOCs will likely result in more SOA formation potential. Existing fuel-effect experimental and model studies have shown that high-aromatic fuel in gasoline fuel will lead to more emissions of primary PM as well as some aromatic VOCs (Zervas et al., 1999; EPA, 2013; Karavalakis et al., 2015; Wang et al., 2016), indicating the considerable potential impact of gasoline aromatic content on SOA production. Furthermore, though aromatic content in diesel fuel may have an insignificant impact on SOA formation (Gordon et al., 2014b), SOA production from gasoline vehicle is considered more sensitive to aromatic content than that from diesel vehicle (Jathar et al., 2013). However, until now, very few studies have successfully quantified the impact of gasoline aromatic content on SOA production and directly revealed the possible pathway.

In this study, in-depth, comprehensive research was conducted to investigate the link between gasoline fuel compositions, primary gas- and particle-phase emission, and corresponding SOA formation. Gasoline exhaust emissions were examined on two platforms under two different conditions. The first platform was a chassis dynamometer system equipped with a constant-volume sampler (CVS). Vehicle exhausts after CVS were introduced into an outdoor environmental chamber and subjected to aging under typical polluted urban conditions to simulate the SOA formation in the ambient atmosphere. The second platform was an experimental engine system on which emissions from a port gasoline injection (PFI) engine and a gasoline direct injection (GDI) engine were examined. SOA formation experiments from engine exhausts were carried out with relatively high $\mathrm{OH}$ exposure compared to ambient conditions to obtain the SOA production potential. Most importantly, different gasoline fuels blended from different refinery streams were utilized in both platforms to probe the critical link among fuel components, VOC emissions and related SOA production.

\section{Materials and methods}

\subsection{Test fleet, cycle and engine}

A commercial PFI vehicle, an experimental PFI engine and a GDI engine were tested in this work.

The chosen PFI vehicle was a commonly used vehicle model in China that was certified to the China IV emission standard (equivalent to Euro 4). The mileage of the test ve- hicles was about $3000 \mathrm{~km}$. The fleet was driven on a chassis dynamometer system (Burke E. Porter Machinery Company) using a cold-start Beijing cycle in order to better simulate the actual driving situation in Beijing. The Beijing cycle was about $17 \mathrm{~min}$ long, with a highest speed of about $50 \mathrm{kmh}^{-1}$ (Fig. S1 in the Supplement). The temperature and the absolute humidity in the dynamometer room were kept at $23.0 \pm 1.0^{\circ} \mathrm{C}$ and $8.4 \pm 0.9 \mathrm{~g} \mathrm{~m}^{-3}$, respectively, for all vehicle experiments (Table $\mathrm{S} 1$ in the Supplement).

Vehicle exhaust underwent the first stage of dilution with filtered ambient air using a CVS operated at $5.5 \mathrm{~m}^{3} \mathrm{~min}^{-1}$ for all experiments. Approximately $5.3 \mathrm{~L} \mathrm{~min}^{-1}$ of diluted exhaust from the CVS was introduced into the $1.2 \mathrm{~m}^{3}$ chamber to be further diluted with the clean air in the chamber (Fig. 1). The average dilution factor was approximately 20 in the CVS and was approximately 15 in the chamber. During the entire cycle, a light-duty gasoline vehicle emissions testing system (Horiba, Ltd.) was used to measure the average and real-time concentration of THC, $\mathrm{CO}_{2}, \mathrm{CO}$ and $\mathrm{NO}_{x}$. In addition, a filter-based sampler (AVL SPC 472) was used to sample primary particles from gasoline vehicles for chemical composition analysis.

The PFI and GDI engines were manufactured by a domestic Chinese automaker and equipped with a turbocharger together with downsized displacement. The PFI engine used in this study was an experimental one with an old three-way catalyst (TWC), while the GDI engine was a commercial one designed for vehicles meeting the China IV emission standard. The operation mode of the PFI and GDI engine for chamber experiments was $2000 \mathrm{rpm}$ with $50 \%$ load. After the engine became stable in this operating mode, the exhaust was introduced into the chamber passing through a heater $\left(150^{\circ} \mathrm{C}\right)$ and a filter, with a flow rate of $5 \mathrm{~L} \mathrm{~min}^{-1}$ and an injection time of $1 \mathrm{~min}$. Particle number, mass and chemical composition, and VOCs in the exhaust were characterized in the same operating mode. Primary particles were sampled by a filter-based sampler (AVL SPC 472) and particulate chemical compositions, i.e., ions, EC, OC and polar and nonpolar organic species, were analyzed using ion chromatography, an EC/OC analyzer (Sunset Laboratory Inc.) and gas chromatography-mass spectrometry (GC-MS) (Guo et al., 2013), respectively. A detailed description of the engine experiments can be found in our previous study (Du et al., 2017), and all engine experiments used in this study are illustrated in Table S2.

\subsection{Fuels}

Three fuels (F1, F2 and F3) were utilized in this study to investigate the impacts of the gasoline fuel on SOA formation. A commercial phase $\mathrm{V}$ gasoline (F1 fuel) with equivalent octane number of 93 was used as the base fuel. F1 fuel contains $29.8 \%$ aromatics and $4.1 \%$ olefin content (Table 1 ). The most abundant species in Fuel 1 was $i$-pentane, followed by toluene and 2-methylpentane (Table S3). 


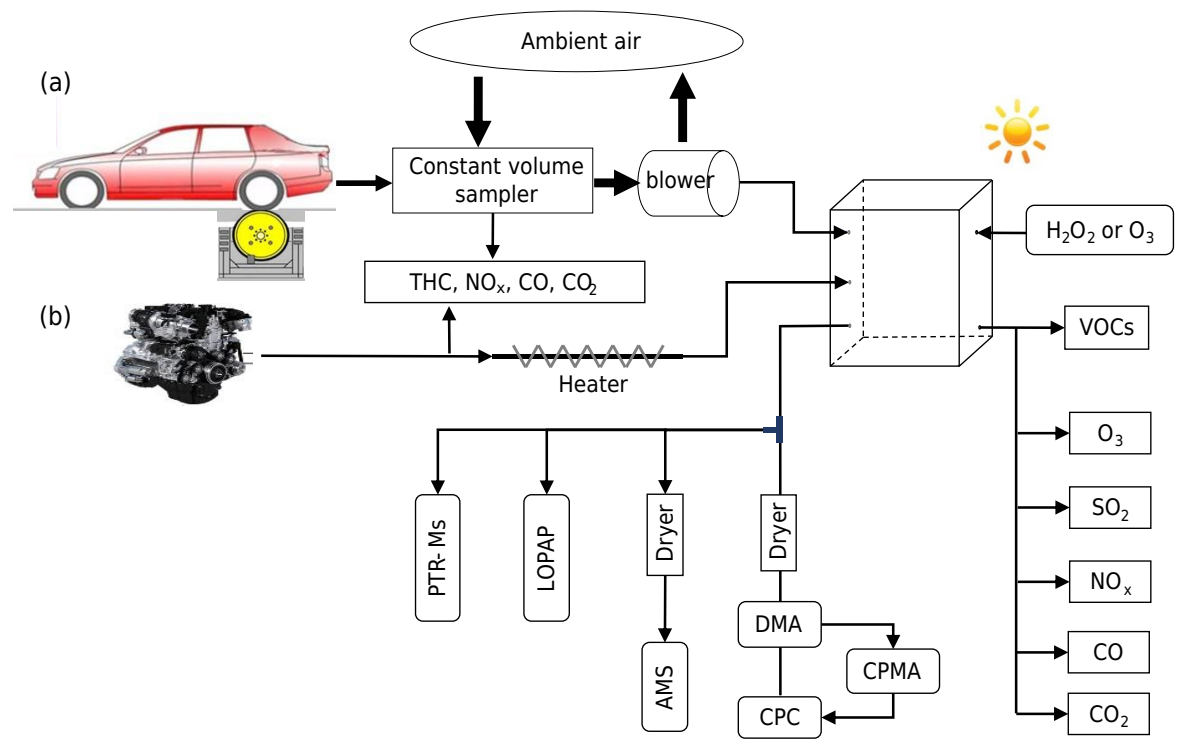

Figure 1. Schematic diagram of chamber experiments.

F2 fuel was blended from $80 \%$ of F6 fuel and $20 \%$ of refinery catalytic stream. Octane $(18.8 \%)$ and aromatic content $(28.5 \%)$ in F2 fuel are very similar to that in F1 fuel, with the only difference being the olefin content.

F3 fuel was blended from $80 \%$ F2 fuel and $15-20 \%$ refinery reformate stream with high aromatic content and a very small amount of $o$-octane and $n$-heptane to keep the same octane level. Compared with F2 fuel, F3 fuel contained similar olefin content $(15.4 \%)$ but higher aromatic content $(36.7 \%)$ (Table 1). In particular, much higher toluene, ethylbenzene and methylethylbenzene were found in F3 fuel (Table S3). Both F2 and F3 fuels meet the phase V gasoline standard. On the basis of the aromatic contents, the F2 and F3 fuel can be well representative of the fuel normally used around year 2010 and after 2013, respectively, on the Chinese market, such as in Beijing and Shanghai.

\subsection{Chamber simulation}

The quasi-atmospheric aerosol evolution study (QUALITY) chamber was utilized to quantify SOA formation from both gasoline engine exhaust and gasoline vehicle exhaust. The $1.2 \mathrm{~m}^{3}$ two-layer chamber is composed of an inner layer of $0.13 \mathrm{~mm}$ PFA Teflon and an outer, rigid, $5.6 \mathrm{~mm}$ thick acrylic shell (Cyro Industries Acrylite, OP-4). Both layers allowed for efficient transmission of sunlight in UV ranges (Peng et al., 2016b). Pre-experiments showed that wall loss decreased the particle number concentration by about $50 \%$ in about $3.5 \mathrm{~h} . \mathrm{SO}_{2}$ and $\mathrm{NO}_{x}$ decreased to about $50 \%$ after $20 \mathrm{~h}$, while toluene and isoprene did not show obvious wall loss during a 2-day experiment (Peng et al., 2017).

Prior to each experiment, the QUALITY chamber was covered with two layers of anti-UV cloth to shield the cham-
Table 1. Parameters of the tested fuels.

\begin{tabular}{lrrr}
\hline Specifications & F1 (base) & $\mathrm{F} 2$ & $\mathrm{~F} 3$ \\
\hline Research octane number & 93.1 & 93.6 & 93 \\
Motor octane numbers & 86.3 & 84.8 & 84 \\
Density $\left(\mathrm{g} \mathrm{mL}^{-1}\right)$ & 0.72 & 0.728 & 0.744 \\
Rvp $(\mathrm{kPa})$ & 58.6 & 63.2 & 55.4 \\
Aromatics $(\% v / v)$ & 29.8 & 28.5 & 36.7 \\
Olefin $(\% v / v)$ & 4.1 & 18.8 & 15.4 \\
Ethanol $(\% v / v)$ & 0.1 & 0.12 & 0.01 \\
Oxygen $(\% \mathrm{~m} / m)$ & 0.01 & 0.06 & 0.02 \\
Mn $\left(\mathrm{mg} \mathrm{kg}^{-1}\right)$ & $<0.1$ & 0.1 & $<0.1$ \\
Sulfur $\left(\mathrm{mg} \mathrm{kg}^{-1}\right)$ & 9 & 7 & 6 \\
T10 $\left({ }^{\circ} \mathrm{C}\right)$ & 50.8 & 50.9 & 55.4 \\
T50 $\left({ }^{\circ} \mathrm{C}\right)$ & 79.4 & 101.9 & 109.9 \\
T90 $\left({ }^{\circ} \mathrm{C}\right)$ & 162.6 & 167.5 & 164.3 \\
Fbp $\left({ }^{\circ} \mathrm{C}\right)$ & 187.9 & 195.7 & 194.4 \\
Quality level & China phase V & China phase V & China phase V \\
\hline
\end{tabular}

ber from sunlight and flushed by zero air with a flow rate of $10 \mathrm{Lmin}^{-1}$ for more than $15 \mathrm{~h}$ to ensure clean conditions. In both vehicle and engine experiments, excess $(1 \mathrm{~mL}$, $30 \% v / v) \mathrm{H}_{2} \mathrm{O}_{2}$ was also injected into the chamber via the makeup zero air as an extra hydroxyl radical $(\mathrm{OH})$ source after adding the exhaust. Chamber experiments were normally conducted from noon to late afternoon, with an inside temperature of $30-35^{\circ} \mathrm{C}$ and relative humidity (RH) of 40 $60 \%$. A suite of high-time-resolution state-of-the-art aerosol instruments were utilized to measure the gas concentration and a comprehensive set of particle properties throughout the experiments, including concentrations of $\mathrm{HONO}, \mathrm{SO}_{2}, \mathrm{NO}_{x}$, $\mathrm{O}_{3}, \mathrm{CO}, \mathrm{CO}_{2}$ and several VOCs and the particle diameter, mass, and chemical composition (Fig. 1 and Table S4).

Particle number distributions were measured with a scanning mobility particle sizer (SMPS) system, which was composed by one differential mobility analyzer (DMA, TSI, 
Inc., model 3081) and one condensation particle counter (CPC, TSI, Inc., model 3772). The mass concentration and size distribution of particle chemical compositions, including organic aerosol (OA), sulfate, nitrate, ammonium and chloride, were measured by a high-resolution time-of-flight aerosol mass spectrometer (HR-ToF-AMS, Aerodyne Research, Inc.). The evolution of several VOCs was measured continually by a proton transfer reaction mass spectrometer (PTR-MS, Ionicon). Dedicated gas monitors, including the $\mathrm{SO}_{2}, \mathrm{NO}_{x}, \mathrm{CO}, \mathrm{CO}_{2}$ and $\mathrm{O}_{3}$ monitors (Thermo Inc.), were utilized and calibrated each experiment day. VOCs in the chamber were also sampled by canisters every $1 \mathrm{~h}$ during vehicle experiments and analyzed with a GC-MS/FID system (Wang et al., 2015).

Zero airflow was connected to the chamber over the entire experiment to make up the volume of air withdrawn by the instruments. To minimize the sampling volume by the instruments, all instruments except SMPS were connected with several three-way valves, which were successively switched between the ambient air and the chamber every 15 or $30 \mathrm{~min}$.

\section{Results}

\subsection{Simulation of SOA formation from gasoline exhausts}

The temporal evolution of gas- and particle-phase species during the chamber experiment is illustrated in Fig. 2. The initial concentrations of $\mathrm{NO}_{x}$, benzene and toluene in the chamber were $163,5.6$ and $16.8 \mathrm{ppb}$, respectively, corresponding to the severe urban haze condition in the megacities (Guo et al., 2014). After the chamber was exposed to sunlight, $99 \%$ of $\mathrm{NO}$ was converted to $\mathrm{NO}_{2}$ within the first $10 \mathrm{~min}$. This is because the fast photolysis of $\mathrm{H}_{2} \mathrm{O}_{2}$ produced a large amount of $\mathrm{OH}$ radical and further $\mathrm{HO}_{2} / \mathrm{RO}_{2}$ radicals inside the chamber, which reacted with $\mathrm{NO}$ to form $\mathrm{NO}_{2}$ (Seinfeld and Pandis, 2006). Then, the concentration of $\mathrm{O}_{3}$ increased rapidly to approximately $400 \mathrm{ppb}$ after $1 \mathrm{~h}$ exposure, and gradually decreased later in this experiment (Fig. 2a).

Over the entire experiment, benzene and toluene experienced a gradual decay in the concentrations, but with different decay coefficients (Fig. 2b). Aerosol evolution is always characterized by a photochemical-age-based parameterization method in ambient measurements as well as chamber experiments (Hu et al., 2013; de Gouw et al., 2005; Peng et al., 2016a). Therefore, in order to compare our SOA productions in different experiments (in which solar flux was different), $\mathrm{OH}$ exposures were calculated based on the ratios of benzene and toluene concentrations, which reacted at different rates with $\mathrm{OH}$ radical (de Gouw et al., 2005). In addition, to compare the $\mathrm{OH}$ exposure in our chamber experiments with the previous ambient measurements, the $\mathrm{OH}$ concentration in the ambient air was assumed as $1.6 \times 10^{6} \mathrm{molec}^{-3}(\mathrm{Hu}$ et al., 2013; Peng et al., 2016a), and the equivalent photo-
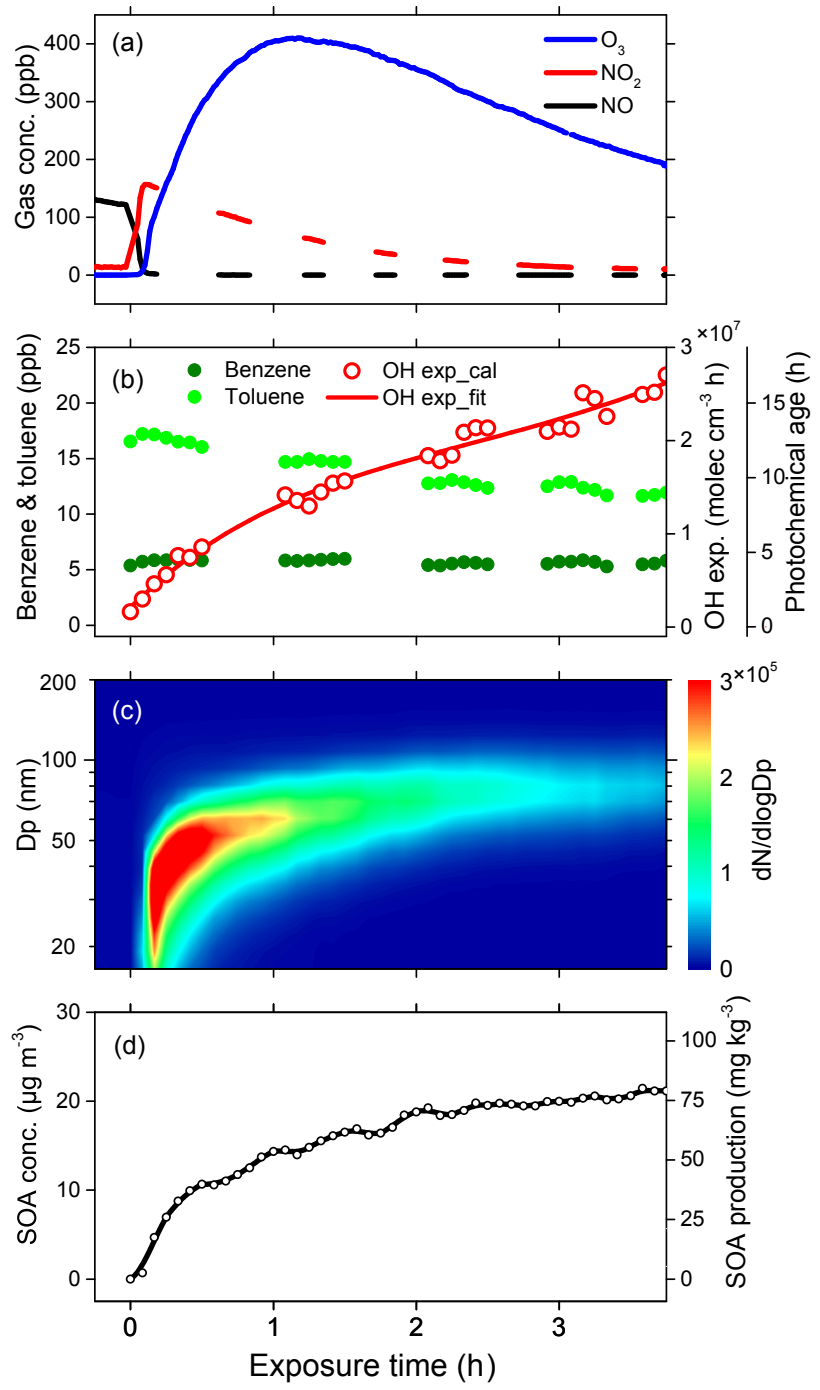

Figure 2. Evolution of gas-phase species $(\mathbf{a}, \mathbf{b})$, particle size distribution (c), and SOA concentration and production (d) during a typical chamber experiment (V2). $\mathrm{OH}$ exposure and photochemical age are calculated based on the ratios of benzene and toluene concentrations, assuming that $\mathrm{OH}$ concentration is $1.6 \times 10^{6} \mathrm{molec} \mathrm{cm}^{-3}$. The SOA mass concentration is obtained by intergrading size distribution of particles inside the chamber on the basis of measured particle density. The measured SOA mass concentration is corrected according to the particle wall loss curve as well as the dilution effect for both particles and gas precursors.

chemical ages of chamber experiments were then estimated by the ratio of $\mathrm{OH}$ exposure in the chamber to the assumed $\mathrm{OH}$ concentration in the ambient air.

New particle formation occurred inside the chamber within $10 \mathrm{~min}$ of exposure to sunlight (Fig. 2c). These newly formed particles performed as seeds for the further formation of secondary species. A large quantity of secondary aerosols was then formed in the chamber, leading to the fast growth in the diameter of these particles to approximately $70 \mathrm{~nm}$ af- 

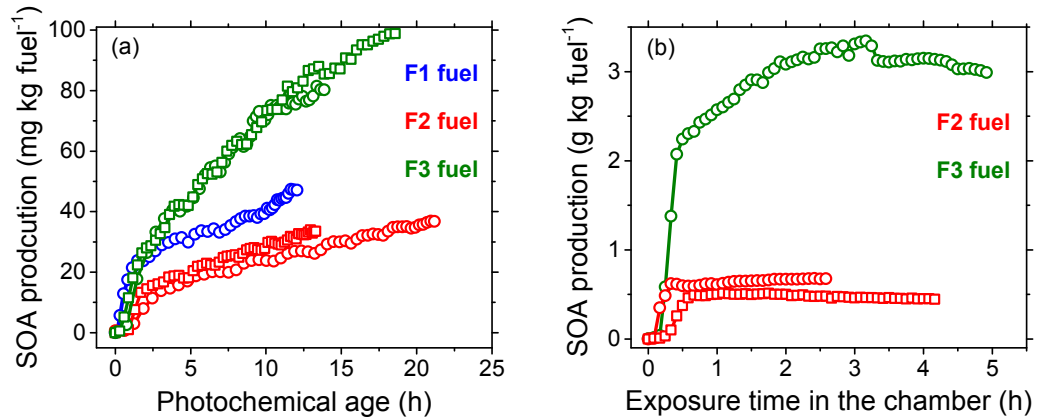

Figure 3. SOA production in the vehicle experiments as a function of photochemical age (a) and in the engine exhaust experiments as a function of exposure time (b). The green squares, green circles, red squares, red circles and blue circles (a) represent experiments V1, V2, V3, V4 and V5 shown in Table S1, respectively. The green circles, red squares and red circles (b) represent experiments E1, E2 and E3 shown in Table $\mathrm{S} 2$, respectively.

ter $3 \mathrm{~h}$ of aging. The measurement of the particle compositions by the AMS reveals that the largest mass fraction of secondary aerosols in the chamber was SOA (approximately $95 \%$, Fig. S2), indicating the critical role of the SOA for the secondary aerosol formation from gasoline exhausts. Because of the low aerosol loading (initially lower than $2 \mu \mathrm{g} \mathrm{m}^{-3}$ ) and low relative humidity (40-50\%) inside the chamber, heterogeneous reactions and aqueous-phase processing were not important for the formation of SOA in this study (Zhang et al., 2015). Furthermore, the O:C ratio of SOA formed in the chamber stayed stable around 0.4 over the entire experiment, indicating that condensed-phase reactions, i.e., aqueous or heterogeneous reactions, which produce highly oxidized oligomers, were not significant in the chamber experiments in this study. The SOA, therefore, was likely formed via condensation of less volatile products oxidized through gas-phase reactions of VOC precursors with limited multigenerational chemistry (Robinson et al., 2007; Jimenez et al., 2009; Jathar et al., 2014). The AMS spectrum profile of gasoline SOA obtained in this study was highly correlated with the ambient less-oxidized secondary organic aerosol (LO-OOA) in Beijing $\left(R^{2}=0.99\right.$, Fig. S3), further confirming the important contribution of gasoline emission on ambient $\mathrm{PM}_{2.5}$.

SOA productions per fuel consumption or mileage were calculated on the basis of SOA mass concentration inside the chamber, dilution factors both in the CVS and inside the chamber, and fuel consumption/mileage of our working cycle. SOA mass concentration inside the chamber was corrected according to the particle wall loss curve (Fig. S4) as well as the dilution effect of both particles and gas precursors due to the continuous zero air flow into the chamber to make up the sampling volume (Fig. S5). SOA production at the end of this experiment was calculated to be $80 \mathrm{mg} \mathrm{kg}^{-f_{u e l}}{ }^{-1}$, or $6.7 \mathrm{mg} \mathrm{km}^{-1}$, after $3.5 \mathrm{~h}$ of aging (Fig. 2d). These values were 6.8 times higher than the emission factors (EFs) of primary particles (including both primary organic matters and elemental carbon) at the same cycle.

\subsection{Fuel impacts on SOA production}

The average fuel consumptions per unit distance using F1, F2 and $\mathrm{F} 3$ fuels were $0.113,0.112$ and $0.113 \mathrm{~L} \mathrm{~km}^{-1}$, respectively, indicating no difference in fuel economy among the three fuels. On the other hand, high-aromatic-content gasoline led to noticeably large enhancement on SOA production from both vehicle and engine experiments. As illustrated in Fig. 3a, the final SOA production from gasoline vehicle exhaust ranged from 30 to $98 \mathrm{mg} \mathrm{kg}$-fuel ${ }^{-1}$ at the end of each experiment, comparable to the results from cold-start experiments in previous studies (Gordon et al., 2014a; Jathar et al., 2014). Experiments using F3 fuel (with $36.7 \% v / v$ aromatic content) exhibit the highest SOA production factors, followed by $\mathrm{F} 1$ fuel (with $29.8 \% v / v$ aromatics content) and $\mathrm{F} 2$ fuel (with $28.5 \% v / v$ aromatics content). The average SOA production at 12 equivalent photochemical hours using F3 fuel was $76 \mathrm{mg} \mathrm{kg}$-fuel $^{-1}\left(6.3 \mathrm{mg} \mathrm{km}^{-1}\right)$, equivalent to 3 times that using F2 fuel $\left(25 \mathrm{mg} \mathrm{kg}\right.$ fuel $\left.^{-1}, 2.1 \mathrm{mg} \mathrm{km}^{-1}\right)$. Additionally, we observed much larger amount of the SOA formation in the first few photochemical hours in all experiments. The average production rates of SOA were as high as $5-13 \mathrm{mg} \mathrm{kg}^{-1} \mathrm{~h}^{-1}$ over each experiment, suggesting that the first-generation oxidation of some precursors inside the chamber produced a large amount of SOA. This indicated the existence of some semi-volatile organic compounds (SVOCs) (Robinson et al., 2007; Keyte et al., 2013). It is worth noting that the higher VOC and SOA concentrations inside the chamber in the F3 fuel experiments might lead to more SVOCs partitioning onto particles. This partitioning, however, would not qualitatively change the experiment conclusion that higher fuel aromatics led to higher SOA production.

SOA formation experiments from the PFI engine exhaust were conducted under high oxidizing conditions to obtain the SOA formation potential. As illustrated in Fig. 3b, most of the SOA was formed within the first half hour of each engine experiment and very little increase was observed over 


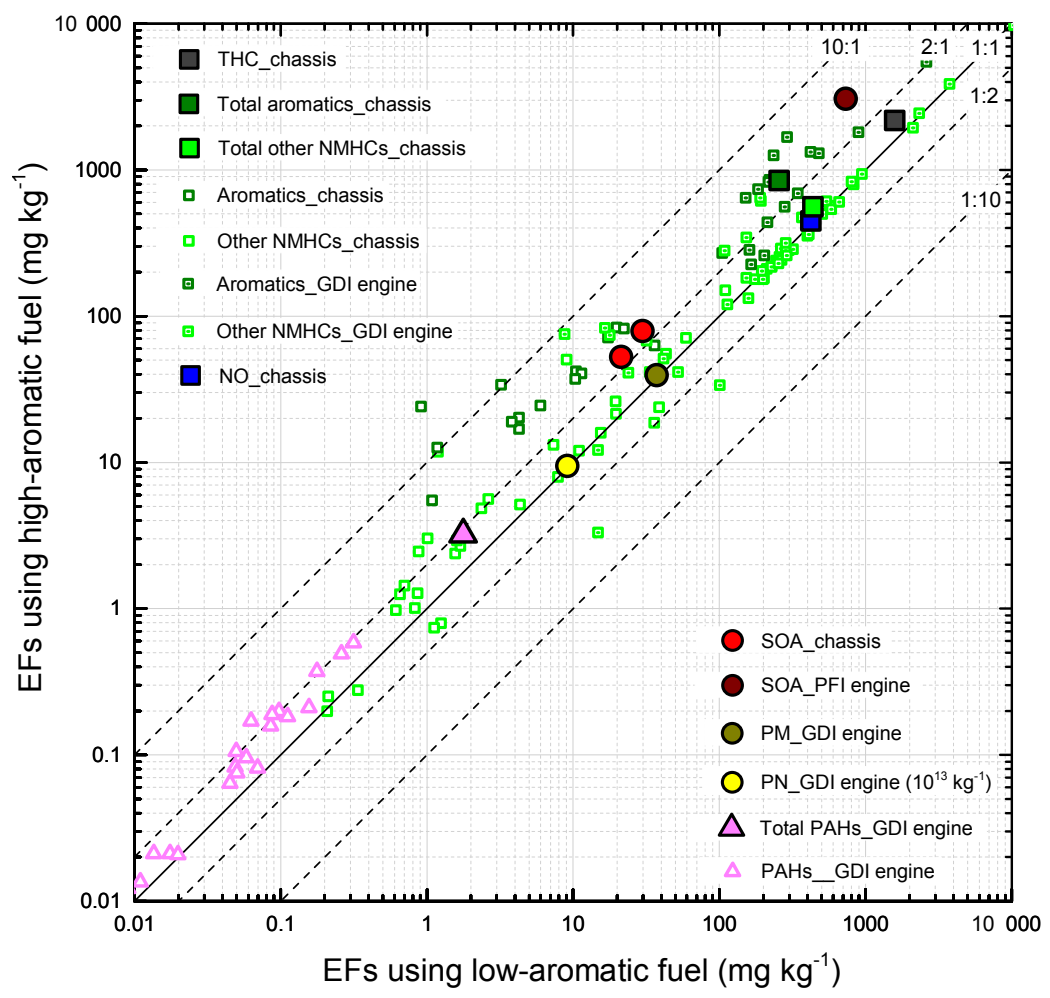

Figure 4. Comparison of emission factors (EFs) of gas and particle species using high-aromatic fuel (F3 fuel) to those using low-aromatic fuel (F2 fuel). The total hydrocarbons (THC) were measured using a vehicle emissions testing system (HORIBA, Ltd.), and the total aromatics and non-methane hydrocarbons (NMHCs) were measured by offline GC-MS. The solid black line denotes where the ratio of EFs using aromatic-rich fuel over aromatic-poor fuel is $1: 1$, and dashed lines show the ratios of $10: 1,2: 1,1: 2$, and $1: 10$. Note that the PAH and VOC data for the GDI engine were measured before the three-way catalyst (TWC). Values in the figure can be found in Table S5.

the following hours. The SOA formation potential from the engine exhaust using F3 fuel was $3.3 \mathrm{~g} \mathrm{~kg}$-fuel ${ }^{-1}$ under these conditions, equivalent to 5.8 times that using F2 fuel, which was $0.57 \mathrm{~g} \mathrm{~kg}^{-f_{u e l}}{ }^{-1}$ on average. The high emission of the experimental PFI engine suggests that the results of engine experiments could represent the SOA production from gasoline vehicles with higher emission factor. Therefore, our results with two different experimental sets (vehicle and engine experiments) demonstrate the applicability of the SOA formation enhancement using high-aromatic fuel for gasoline vehicle with either high or low emission factor, under either representative cycle conditions or steady-state operating conditions.

Though good reproducibility was found for SOA production using either F2 or F3 fuels, there were inevitably several biases in the chamber simulation approach. For example, the SOA production in both vehicle and engine experiments might be underestimated due to loss of SVOC vapors to the chamber wall as well as the condensation of low organic vapor onto the particles that were already lost on the chamber wall (Zhang et al., 2014). Also, the SOA production in engine experiments could be overestimated because the high concentration in the chamber might drive the gas-particle par- titioning of the SVOCs into particle phase (Robinson et al., 2007). Nevertheless, the relative enhancement factor of SOA for different fuels was not largely influenced by these biases.

\subsection{Aromatic emission and SOA production}

To reveal the reason for this large amplification on SOA production owing to fuel constitution, gasoline PM and VOC emissions using F2 and F3 fuels were investigated (Fig. 4). Significant differences in the EFs among different gas- and particle-phase species were observed. For example, the EFs of primary PM in both number and mass concentration using F3 fuel were only $20 \%$ larger than those using F2 fuel, consistent with previous studies (EPA, 2013; Karavalakis et al., 2015). Similar results were also obtained for most of the alkane VOCs as well as NO. However, the EFs for SOA, aromatic VOCs and particle-phase polycyclic aromatic hydrocarbons (PAHs) exhibited marked enhancement using higharomatic gasoline fuel. The EFs of each aromatic VOCs from the exhaust experiment increased by a factor of 0.2-9.5 using high-aromatic gasoline fuel, with enhancement factors of 3.3 and 2.7 for total aromatic VOCs in vehicle and engine experiments, respectively (Fig. 4). Coincidentally, the total particle-phase PAH emission was amplified by 1.8 times us- 

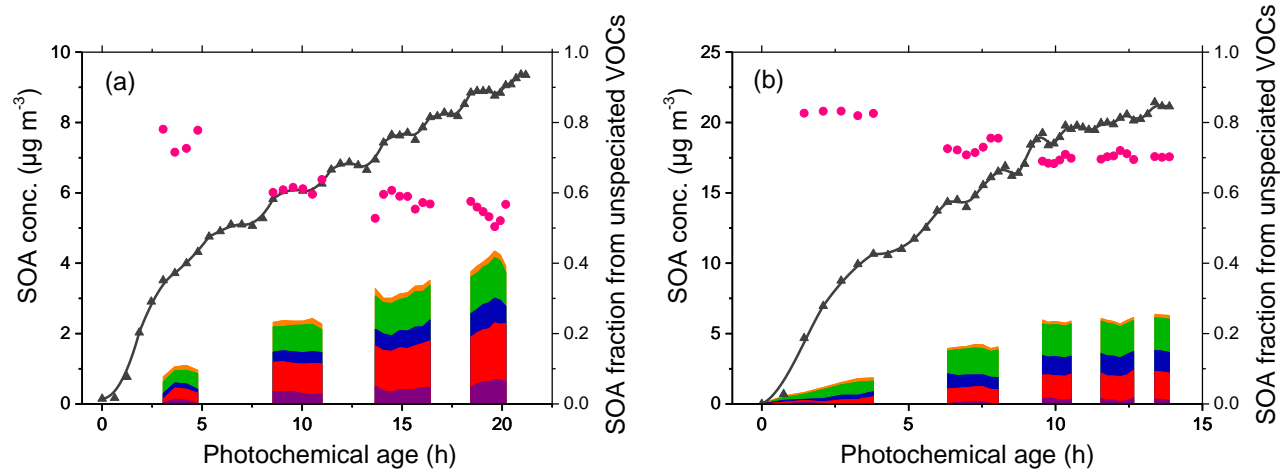

Figure 5. Observed and predicted SOA concentration as well as SOA fraction from unspeciated VOCs as a function of photochemical age in typical chamber experiments using (a) F2 (experiment V4) and (b) F3 (experiment V2) fuels. The black line and triangles represent the corrected SOA concentrations in the chamber experiments. The purple, red, blue, green and yellow areas represent the predicted SOA from the oxidation of benzene, toluene, $\mathrm{C}_{8}$ aromatics, $\mathrm{C}_{9}$ aromatics and styrene, respectively. The pink circles represent the SOA fractions that cannot be predicted by the one-ring aromatic VOC precursors.

ing high-aromatic gasoline fuel (F3 vs. F2), with the amplification factor of each PAH species varying from 1.1 to 2.2. Since both gas-phase aromatic VOCs (one ring) and particlephase PAHs (mostly 3-7 rings) exhibited much higher EFs using high-aromatic gasoline fuel, it is reasonable to speculate higher EFs of the semi-volatile PAHs (2-3 rings) in our experiments.

Aromatic components in the exhaust mainly come from two routes, which are the survival of fuel aromatic contents and the combustion-derived formation in the engine. Ethylene and acetylene are the key species for the combustionderived aromatics. High concentrations of ethylene and acetylene accelerate the acetylene addition reaction, which generates light aromatic VOCs as well as PAHs in the engine (Wang and Frenklach, 1997; Frenklach, 2002). In this study, when the high-aromatic fuel was used, the concentrations of ethylene and acetylene from the GDI engine were enhanced by a factor of 3.3 and 2.7, respectively, indicating that more aromatics were formed through the addition reaction of acetylene and ethylene in the engine.

SOA production $\left(\triangle O \mathrm{OA}_{\text {predicted }}\right)$ from $\mathrm{VOC}$ precursors in the exhaust was roughly estimated by multiplying the mass loss of each VOC precursors $(\Delta i)$ by its SOA yield, $Y_{i}$ (Donahue et al., 2006):

$\Delta \mathrm{OA}_{\text {predicted }}=\sum_{i}\left(\Delta_{i} \times Y_{i}\right)$

The SOA precursors here included benzene, toluene, $\mathrm{C}_{8}$ aromatics, $\mathrm{C}_{9}$ aromatics and styrene, which were all measured by PTR-MS during each experiment. The contributions of the alkenes and alkanes (7-11 carbons) to SOA formation in our experiments were also estimated using Eq. (1) based on the offline GC-MS measurement. Results showed that the measured alkenes and alkanes (7-11 carbons) only accounted for approximately $4 \%$ of the total predicted SOA concentration (Fig. S6) due to the low emission factors as well as the small reacted proportion of these species inside the chamber. The yields of VOCs under high- $\mathrm{NO}_{x}$ conditions are used (Ng et al., 2007; Platt et al., 2013), due to the low initial $\mathrm{VOC} / \mathrm{NO}_{x}$ ratios, which ranged from 0.5 to 1.0.

Figure 5 shows the two typical vehicle experiments with observed and predicted SOA concentration as a function of photochemical age using F2 and F3 fuels, respectively. The predicted SOA in the end of the two experiments accounted for 46 and $30 \%$ of the observed SOA formation with toluene and $\mathrm{C}_{9}$ aromatics to be the largest contributors, consistent with the previous results (Nordin et al., 2013; Platt et al., 2013; Gordon et al., 2014a). The predicted SOA concentration using F3 fuel was about $90 \%$ higher than that using F2 fuel, suggesting the important role of single-ring aromatic VOCs on the enhancement of SOA formation using higharomatic fuel. However, more than $50 \%$ of the SOA concentration cannot be explained by gas-phase oxidation of these single-ring aromatic VOCs. This value was even higher (up to $80 \%$ ) in the first few photochemical hours in both experiments. Additionally, a much larger percentage of SOA using F3 fuel cannot be explained by the single-ring aromatic VOCs. This suggests the existence of some unspeciated organic vapors, most likely SVOCs, which are considered to have high SOA yield and might partition to particle phase after the first-generation oxidation (Robinson et al., 2007; Chan et al., 2009; Jathar et al., 2014; T. Liu et al., 2015). Two-ring and three-ring PAHs, e.g., naphthalene and phenanthrene, which were proven to have higher EFs using high-aromatic fuel (Chan et al., 2009), likely contributed importantly to the SVOC vapors and might play a crucial role in the enhancement of SOA production using high-aromatic fuel. 


\section{Discussion}

Our results show the critical impact of gasoline aromatics on urban SOA formation. We observed an amplification factor of 3-6 on SOA formation using high-aromatic gasoline, which was mainly caused by the high emission of one-ring aromatic VOCs as well as SVOCs such as gas-phase PAHs. This enhancement of SOA formation, meanwhile, was found using not only a new vehicle meeting the China IV emission standard, operated under representative cycle conditions in Beijing, but also an experimental engine which emitted more gaseous pollutants and was operated at steady state, suggesting the extensive applicability of our results.

Moreover, photo-oxidation of aromatics leads to significant production of small dicarbonyls, i.e., glyoxal and methylglyoxal, which have high SOA yield via aqueous reactions (Zhang et al., 2015). If this aqueous SOA pathway is taken into account, the influence of fuel on SOA formation will be much more remarkable. More work is needed to evaluate the aqueous pathway of SOA formation from gasoline exhaust.

Currently, aromatic content in gasoline fuel is increasing continuously in China, where more a stringent standard on gasoline sulfur content has been implemented and oil refining procedures are changing to meet the new standard. For example, we found that the average aromatic contents for gasoline fuel on the market meeting the Beijing III, IV and V standards were $23.4,28.5$ and $36.3 \%$, respectively. A recent study found that gasoline aromatic content in China was 9.6\% higher than that in the USA (Tang et al., 2015). Hence, the enhancement in SOA formation resulting from the increase in aromatic content in gasoline fuel from 29 to $37 \%$ in this study can well represent the extra SOA formation due to the gasoline standard change in Beijing. Neglecting this side effect of fuel standard change may potentially offset the considerable endeavors to control vehicle emission undertaken by the local government. From another perspective, our findings provide a new direction in controlling air pollution from vehicles, which is to decrease the aromatic content in the gasoline fuel. This may require more hydrogenation catalysis processes in the petroleum refining procedure instead of catalytic reforming processes, in which a large amount of aromatic contents might be produced. Compared with the vehicle restriction regulation which attracted a lot of criticism from society and the elimination of polluting vehicles which came at considerable expense, this direction might be more acceptable, efficient and economical. Additionally, the current vehicle emission evaluation system, which mainly measures the emissions of PM, THC, $\mathrm{NO}_{x}$ and $\mathrm{CO}$, will fail to tell of the consequences of using high-aromatic gasoline fuel, as these species do not increase much when high-aromatic fuel is used (Fig. 4). Aromatic VOCs, especially SVOCs, should be considered in future vehicle emission evaluation.

Furthermore, this influence of gasoline aromatic content on air quality is not only adoptable in China. Strikingly, the current standards on gasoline aromatic content are not stringent enough in most of the countries and regions in the world where fuel standards with very high maximum gasoline aromatic content (ranging from 35 to $42 \%$ in different countries, Table S6) are implemented, even including developed countries and regions such as Europe, Japan and Australia. Our findings highlight the necessity of a more stringent regulation of gasoline aromatic content in the next renewal of the gasoline standard.

Data availability. The data presented in this paper are available from the author upon request (minhu@ pku.edu.cn).

\section{The Supplement related to this article is available online at https://doi.org/10.5194/acp-17-10743-2017- supplement.}

Competing interests. The authors declare that they have no conflict of interest.

Acknowledgement. This work was supported by the National Basic Research Program of China (973 Program) (2013CB228503, 2013CB228502, 2013CB955801), the National Natural Science Foundation of China (91544214, 51636003, 41421064), the Strategic Priority Research Program of Chinese Academy of Sciences (XDB05010500), and the China Postdoctoral Science Foundation (2015M580929). The authors thank Jianhua Xiao and Lei Deng at Tsinghua University for their contribution to this work.

Edited by: Nga Lee $\mathrm{Ng}$

Reviewed by: two anonymous referees

\section{References}

Bahreini, R., Middlebrook, A. M., de Gouw, J. A., Warneke, C., Trainer, M., Brock, C. A., Stark, H., Brown, S. S., Dube, W. P., Gilman, J. B., Hall, K., Holloway, J. S., Kuster, W. C., Perring, A. E., Prevot, A. S. H., Schwarz, J. P., Spackman, J. R., Szidat, S., Wagner, N. L., Weber, R. J., Zotter, P., and Parrish, D. D.: Gasoline emissions dominate over diesel in formation of secondary organic aerosol mass, Geophys. Res. Lett., 39, L06805, https://doi.org/10.1029/2011g1050718, 2012.

Chan, A. W. H., Kautzman, K. E., Chhabra, P. S., Surratt, J. D., Chan, M. N., Crounse, J. D., Kürten, A., Wennberg, P. O., Flagan, R. C., and Seinfeld, J. H.: Secondary organic aerosol formation from photooxidation of naphthalene and alkylnaphthalenes: implications for oxidation of intermediate volatility organic compounds (IVOCs), Atmos. Chem. Phys., 9, 3049-3060, https://doi.org/10.5194/acp-9-3049-2009, 2009.

de Gouw, J. A., Middlebrook, A. M., Warneke, C., Goldan, P. D., Kuster, W. C., Roberts, J. M., Fehsenfeld, F. C., Worsnop, D. R., Canagaratna, M. R., Pszenny, A. A. P., Keene, W. C., Marchewka, M., Bertman, S. B., and Bates, T. S.: Budget of 
organic carbon in a polluted atmosphere: results from the New England Air Quality Study in 2002, J. Geophys. Res.-Atmos., 110, D16305, https://doi.org/10.1029/2004jd005623, 2005.

Donahue, N. M., Robinson, A. L., Stanier, C. O., and Pandis, S. N.: Coupled partitioning, dilution, and chemical aging of semivolatile organics, Environ. Sci. Technol., 40, 2635-2643, https://doi.org/10.1021/es052297c, 2006.

Du, Z., Hu, M., Peng, J., Guo, S., Zheng, R., Zheng, J., Shang, D., Qin, Y., Niu, H., Li, M., Yang, Y., Lu, S., Wu, Y., Shao, M., and Shuai, S.: Potential of secondary aerosol formation from Chinese gasoline engine exhaust, J. Environ. Sci., https://doi.org/10.1016/j.jes.2017.02.022, online first, 2017.

Energy Information Administration US (EIA): August 2017 Monthly Energy Review, DOE/EIA-0035(2017/08), available at: http://www.eia.gov/totalenergy/data/monthly/pdf/mer. pdf (last access: 7 September 2017), 2017.

EPA (Environmental Protection Agency US): Assessing the Effect of Five Gasoline Properties on Exhaust Emissions from LightDuty Vehicles Certified to Tier 2 Standards: Analysis of Data from EPAct Phase 3, EPA-420-R-13-002:232-233, 2013.

Frenklach, M.: Reaction mechanism of soot formation in flames, Phys. Chem. Chem. Phys., 4, 2028-2037, https://doi.org/10.1039/b110045a, 2002.

Gordon, T. D., Presto, A. A., May, A. A., Nguyen, N. T., Lipsky, E. M., Donahue, N. M., Gutierrez, A., Zhang, M., Maddox, C., Rieger, P., Chattopadhyay, S., Maldonado, H., Maricq, M. M., and Robinson, A. L.: Secondary organic aerosol formation exceeds primary particulate matter emissions for lightduty gasoline vehicles, Atmos. Chem. Phys., 14, 4661-4678, https://doi.org/10.5194/acp-14-4661-2014, 2014a.

Gordon, T. D., Presto, A. A., Nguyen, N. T., Robertson, W. H., Na, K., Sahay, K. N., Zhang, M., Maddox, C., Rieger, P., Chattopadhyay, S., Maldonado, H., Maricq, M. M., and Robinson, A. L.: Secondary organic aerosol production from diesel vehicle exhaust: impact of aftertreatment, fuel chemistry and driving cycle, Atmos. Chem. Phys., 14, 4643-4659, https://doi.org/10.5194/acp-14-4643-2014, 2014 b.

Guo, S., Hu, M., Guo, Q., Zhang, X., Schauer, J. J., and Zhang, R.: Quantitative evaluation of emission controls on primary and secondary organic aerosol sources during Beijing 2008 Olympics, Atmos. Chem. Phys., 13, 8303-8314, https://doi.org/10.5194/acp-13-8303-2013, 2013.

Guo, S., Hu, M., Zamora, M. L., Peng, J. F., Shang, D. J., Zheng, J., Du, Z. F., Wu, Z., Shao, M., Zeng, L. M., Molina, M. J., and Zhang, R. Y.: Elucidating severe urban haze formation in China, P. Natl. Acad. Sci. USA, 111, 17373-17378, https://doi.org/10.1073/pnas.1419604111, 2014.

Hu, W. W., Hu, M., Yuan, B., Jimenez, J. L., Tang, Q., Peng, J. F., Hu, W., Shao, M., Wang, M., Zeng, L. M., Wu, Y. S., Gong, Z. H., Huang, X. F., and He, L. Y.: Insights on organic aerosol aging and the influence of coal combustion at a regional receptor site of central eastern China, Atmos. Chem. Phys., 13, 10095-10112, https://doi.org/10.5194/acp-13-10095-2013, 2013.

Huang, R.-J., Zhang, Y., Bozzetti, C., Ho, K.-F., Cao, J.-J., Han, Y., Daellenbach, K. R., Slowik, J. G., Platt, S. M., Canonaco, F., Zotter, P., Wolf, R., Pieber, S. M., Bruns, E. A., Crippa, M., Ciarelli, G., Piazzalunga, A., Schwikowski, M., Abbaszade, G., Schnelle-Kreis, J., Zimmermann, R., An, Z., Szidat, S., Baltensperger, U., Haddad, I. E., and Prévôt, A. S. H.:
High secondary aerosol contribution to particulate pollution during haze events in China, Nature, 514, 218-222, https://doi.org/10.1038/nature13774, 2014.

Jathar, S. H., Miracolo, M. A., Tkacik, D. S., Donahue, N. M., Adams, P. J., and Robinson, A. L.: Secondary organic aerosol formation from photo-oxidation of unburned fuel: experimental results and implications for aerosol formation from combustion emissions, Environ. Sci. Technol., 47, 12886-12893, https://doi.org/10.1021/es403445q, 2013.

Jathar, S. H., Gordon, T. D., Hennigan, C. J., Pye, H. O., Pouliot, G., Adams, P. J., Donahue, N. M., and Robinson, A. L.: Unspeciated organic emissions from combustion sources and their influence on the secondary organic aerosol budget in the United States, P. Natl. Acad. Sci. USA, 111, 10473-10478, https://doi.org/10.1073/pnas.1323740111, 2014.

Jimenez, J. L., Canagaratna, M. R., Donahue, N. M., Prevot, A. S. H., Zhang, Q., Kroll, J. H., DeCarlo, P. F., Allan, J. D. Coe, H., Ng, N. L., Aiken, A. C., Docherty, K. S., Ulbrich, I. M., Grieshop, A. P., Robinson, A. L., Duplissy, J., Smith, J. D., Wilson, K. R., Lanz, V. A., Hueglin, C., Sun, Y. L., Tian, J., Laaksonen, A., Raatikainen, T., Rautiainen, J., Vaattovaara, P., Ehn, M., Kulmala, M., Tomlinson, J. M., Collins, D. R., Cubison, M. J., Dunlea, J., Huffman, J. A., Onasch, T. B., Alfarra, M. R., Williams, P. I., Bower, K., Kondo, Y., Schneider, J., Drewnick, F. Borrmann, S., Weimer, S., Demerjian, K., Salcedo, D., Cottrell, L., Griffin, R., Takami, A., Miyoshi, T., Hatakeyama, S., Shimono, A., Sun, J. Y., Zhang, Y. M., Dzepina, K., Kimmel, J. R., Sueper, D., Jayne, J. T., Herndon, S. C., Trimborn, A. M., Williams, L. R., Wood, E. C., Middlebrook, A. M., Kolb, C. E., Baltensperger, U., and Worsnop, D. R.: Evolution of organic aerosols in the atmosphere, Science, 326, 1525-1529, https://doi.org/10.1126/science.1180353, 2009.

Karavalakis, G., Short, D., Vu, D., Russell, R., Hajbabaei, M., AsaAwuku, A., and Durbin, T. D.: Evaluating the effects of aromatics content in gasoline on gaseous and particulate matter emissions from SI-PFI and SIDI vehicles, Environ. Sci. Technol., 49, 70217031, https://doi.org/10.1021/es5061726, 2015.

Kelly, F. J. and Zhu, T.: Transport solutions for cleaner air, Science, 352, 934-936, https://doi.org/10.1126/science.aaf3420, 2016.

Keyte, I. J., Harrison, R. M., and Lammel, G.: Chemical reactivity and long-range transport potential of polycyclic aromatic hydrocarbons - a review, Chem. Soc. Rev., 42, 9333-9391, https://doi.org/10.1039/c3cs60147a, 2013.

Kumar, P., Morawska, L., Birmili, W., Paasonen, P., Hu, M., Kulmala, M., Harrison, R. M., Norford, L., and Britter, R.: Ultrafine particles in cities, Environ. Int., 66, 1-10, https://doi.org/10.1016/j.envint.2014.01.013, 2014.

Liu, S., Aiken, A. C., Gorkowski, K., Dubey, M. K., Cappa, C. D., Williams, L. R., Herndon, S. C., Massoli, P., Fortner, E. C., Chhabra, P. S., Brooks, W. A., Onasch, T. B., Jayne, J. T., Worsnop, D. R., China, S., Sharma, N., Mazzoleni, C., Xu, L., Ng, N. L., Liu, D., Allan, J. D., Lee, J. D., Fleming, Z. L., Mohr, C., Zotter, P., Szidat, S., and Prevot, A. S. H.: Enhanced light absorption by mixed source black and brown carbon particles in UK winter, Nat. Commun., 6, 8435, https://doi.org/10.1038/Ncomms9435, 2015.

Liu, T., Wang, X., Deng, W., Hu, Q., Ding, X., Zhang, Y., He, Q., Zhang, Z., Lü, S., Bi, X., Chen, J., and Yu, J.: Secondary organic aerosol formation from photochemical aging of light- 
duty gasoline vehicle exhausts in a smog chamber, Atmos. Chem. Phys., 15, 9049-9062, https://doi.org/10.5194/acp-159049-2015, 2015.

NBSC National Bureau of Statistics of China: China Statistical Yearbook, China Statistics Press, 2015.

Ng, N. L., Kroll, J. H., Chan, A. W. H., Chhabra, P. S., Flagan, R. C., and Seinfeld, J. H.: Secondary organic aerosol formation from $m$-xylene, toluene, and benzene, Atmos. Chem. Phys., 7, 3909-3922, https://doi.org/10.5194/acp-7-3909-2007, 2007.

Nordin, E. Z., Eriksson, A. C., Roldin, P., Nilsson, P. T., Carlsson, J. E., Kajos, M. K., Hellén, H., Wittbom, C., Rissler, J., Löndahl, J., Swietlicki, E., Svenningsson, B., Bohgard, M., Kulmala, M., Hallquist, M., and Pagels, J. H.: Secondary organic aerosol formation from idling gasoline passenger vehicle emissions investigated in a smog chamber, Atmos. Chem. Phys., 13, 6101-6116, https://doi.org/10.5194/acp-13-6101-2013, 2013.

Parrish, D. D. and Zhu, T.: Clean air for megacities, Science, 326, 674-675, https://doi.org/10.1126/science.1176064, 2009.

Peng, J. F., Hu, M., Gong, Z. H., Tian, X. D., Wang, M., Zheng, J., Guo, Q. F., Cao, W., Lv, W., Hu, W. W., $\mathrm{Wu}$, Z. J., and Guo, S.: Evolution of secondary inorganic and organic aerosols during transport: A case study at a regional receptor site, Environ. Pollut., 218, 794-803, https://doi.org/10.1016/j.envpol.2016.08.003, 2016a.

Peng, J. F., Hu, M., Guo, S., Du, Z. F., Zheng, J., Shang, D. J., Zamora, M. L., Zeng, L. M., Shao, M., Wu, Y. S., Zheng, J., Wang, Y., Glen, C. R., Collins, D. R., Molina, M. J., and Zhang, R. Y.: Markedly enhanced absorption and direct radiative forcing of black carbon under polluted urban environments, P. Natl. Acad. Sci. USA, 113, 4266-4271, https://doi.org/10.1073/pnas.1602310113, 2016b.

Peng, J., Hu, M., Guo, S., Du, Z., Shang, D., Zheng, J., Zheng, J., Zeng, L., Shao, M., Wu, Y., Collins, D., and Zhang, R.: Ageing and hygroscopicity variation of black carbon particles in Beijing measured by a quasi-atmospheric aerosol evolution study (QUALITY) chamber, Atmos. Chem. Phys., 17, 10333-10348, https://doi.org/10.5194/acp-17-10333-2017, 2017.

Platt, S. M., El Haddad, I., Zardini, A. A., Clairotte, M., Astorga, C., Wolf, R., Slowik, J. G., Temime-Roussel, B., Marchand, N., Ježek, I., Drinovec, L., Močnik, G., Möhler, O., Richter, R., Barmet, P., Bianchi, F., Baltensperger, U., and Prévôt, A. S. H.: Secondary organic aerosol formation from gasoline vehicle emissions in a new mobile environmental reaction chamber, Atmos. Chem. Phys., 13, 9141-9158, https://doi.org/10.5194/acp13-9141-2013, 2013.

Platt, S. M., El Haddad, I., Pieber, S. M., Huang, R. J., Zardini, A. A., Clairotte, M., Suarez-Bertoa, R., Barmet, P., Pfaffenberger, L., Wolf, R., Slowik, J. G., Fuller, S. J., Kalberer, M., Chirico, R., Dommen, J., Astorga, C., Zimmermann, R., Marchand, N., Hellebust, S., Temime-Roussel, B., Baltensperger, U., and Prevot, A. S. H.: Two-stroke scooters are a dominant source of air pollution in many cities, Nat. Commun., 5, 3749, https://doi.org/10.1038/Ncomms4749, 2014.
Robinson, A. L., Donahue, N. M., Shrivastava, M. K., Weitkamp, E. A., Sage, A. M., Grieshop, A. P., Lane, T. E., Pierce, J. R., and Pandis, S. N.: Rethinking organic aerosols: semivolatile emissions and photochemical aging, Science, 315, 1259-1262, https://doi.org/10.1126/science.1133061, 2007.

Schwantes, R. H., Schilling, K. A., McVay, R. C., Lignell, H., Coggon, M. M., Zhang, X., Wennberg, P. O., and Seinfeld, J. H.: Formation of highly oxygenated low-volatility products from cresol oxidation, Atmos. Chem. Phys., 17, 3453-3474, https://doi.org/10.5194/acp-17-3453-2017, 2017.

Seinfeld, J. H. and Pandis, S. N.: Atmospheric Chemistry and Physics: From Air Pollution to Climate Change, 2nd Edn., J. Wiley, New York, 2006.

Tang, G., Sun, J., Wu, F., Sun, Y., Zhu, X., Geng, Y., and Wang, Y.: Organic composition of gasoline and its potential effects on air pollution in North China, Sci. China Chem., 58, 1416-1425, https://doi.org/10.1007/s11426-015-5464-0, 2015.

Wang, H. and Frenklach, M.: A detailed kinetic modeling study of aromatics formation in laminar premixed acetylene and ethylene flames, Combust. Flame, 110, 173-221, https://doi.org/10.1016/S0010-2180(97)00068-0, 1997.

Wang, M., Shao, M., Chen, W., Lu, S., Liu, Y., Yuan, B., Zhang, Q., Zhang, Q., Chang, C.-C., Wang, B., Zeng, L., Hu, M., Yang, Y., and Li, Y.: Trends of non-methane hydrocarbons (NMHC) emissions in Beijing during 2002-2013, Atmos. Chem. Phys., 15, 1489-1502, https://doi.org/10.5194/acp-15-1489-2015, 2015.

Wang, Y., Zheng, R., Qin, Y., Peng, J., Li, M., Xing, J., Wu, Y., $\mathrm{Hu}, \mathrm{M}$., and Shuai, S.: The impact of fuel compositions on the particulate emissions of direct injection gasoline engine, Fuel, 166, 543-552, https://doi.org/10.1016/j.fuel.2015.11.019, 2016.

Zervas, E., Montagne, X., and Lahaye, J.: The influence of gasoline formulation on specific pollutant emissions, J. Air Waste. Manage., 49, 1304-1314, 1999.

Zhang, R., Wang, G., Guo, S., Zamora, M. L., Ying, Q., Lin, Y., Wang, W., Hu, M., and Wang, Y.: Formation of urban fine particulate matter, Chem. Rev., 115, 3803-3855, https://doi.org/10.1021/acs.chemrev.5b00067, 2015.

Zhang, X., Cappa, C. D., Jathar, S. H., Mcvay, R. C., Ensberg, J. J., Kleeman, M. J., and Seinfeld, J. H.: Influence of vapor wall loss in laboratory chambers on yields of secondary organic aerosol, P. Natl. Acad. Sci. USA, 111, 5802-5807, https://doi.org/10.1073/pnas.1404727111, 2014. 